\title{
Moderating Role of Audit Fees on the Effect of Task Complexity and Independence towards Audit Judgment
}

\author{
Nur Eny ${ }^{1}$, Ratna Mappanyukki ${ }^{2}$ \\ ${ }^{1}$ Faculty of Economic and Business, State University of Makassar (UNM), Makassar, Indonesia \\ ${ }^{2}$ Faculty of Economic and Business, Mercu Buana University, Jakarta, Indonesia
}

\author{
A R T I C L E I N F O \\ Article history: \\ Received 02 September 2020 \\ Revised 28 October 2020 \\ Accepted 29 November 2020

\section{JEL Classification:} \\ J24, M41, M42 \\ Key words: \\ Task complexity, Independence, Audit \\ Judgment, Audit Fee.
}

DOI:

10.14414/jebav.v23i2.2326

\begin{abstract}
A B S T R A C T
This study examines the effect of task complexity and auditor independence on audit judgment with audit fees as a moderating variable. Samples were obtained from auditors working in public accounting firms in West Jakarta and South Jakarta. Data collec-tion was done using a survey method by distributing questionnaires to 100 auditors as respondents. The method of analysis used was Moderated Regression Analysis. The results show that task complexity hurts audit judgment. Auditor independence has a positive effect on audit judgment. Audit fees can strengthen the effect of task complexity on audit judgment. Besides, audit fees moderate the effect of auditor independence on audit judgment. It is recommended that public accounting firms consider the inter-action of variables that affect audit judgment, such as task complexity, independence, and audit fees, to improve audit quality.
\end{abstract}

\begin{abstract}
A B S T R A K
Penelitian ini menguji pengaruh kompleksitas tugas dan independensi auditor terhadap audit judgment dengan audit fee sebagai variabel moderasi. Sampel diperoleh dari auditor yang bekerja di Kantor Akuntan Publik di Jakarta Barat dan Jakarta Selatan. Data diperoleh melalui metode survey dengan menyebarkan kuesioner kepada 100 auditor sebagai responden. Metode analisis yang digunakan adalah Analisis Regresi Moderasi (Moderated Regression Analysis). Hasil analisis menunjukan bahwa kompleksitas tugas berpengaruh negatif terhadap audit judgment, independensi auditor berpengaruh positif terhadap audit judgment, audit fee dapat menguatkan pengaruh kompleksitas tugas terhadap audit judgement. Temuan penelitian ini juga menunjukkan bahwa audit fee memoderasi pengaruh independensi auditor ter-hadap audit judgement. Penelitian ini menyarankan agar Kantor Akuntan Publik memperhitungkan interaksi variabel yang mempengaruhi audit judgement, seperti kompleksitas tugas, independensi, dan biaya audit, untuk meningkatkan kualitas audit.
\end{abstract}

\section{INTRODUCTION}

The phenomenon of audit failure has created a crisis of confidence in the performance of public accountants. In carrying out their duties and responsibilities, public accountants have social duties expected by many parties to provide certainty on the appropriateness of financial reports and be responsible for the opinions given based on the professional code of ethics. The auditor not only provides an opinion on the financial statements but is also required to provide an audit planning program, including a process for evaluating the audited financial statements. When conducting an audit, the auditor performs a verification process that requires the implementation of the audit program properly and reports any violations found based on the available evidence with correct judgment, which may result in a fair opinion.

Audit failure can be seen from the number of financial reports that received an Unqualified opinion but instead went bankrupt (Pasanda and Paranoan, 2013). Several cases involving large public accounting firms include the case of PT. Jiwasraya, the case of PT. Sunprima Nusantara Pembiayaan (SNP Finance), and the case of PT. Garuda Indonesia. Price Waterhouse Coopers (PwC), a Public Accounting Firm, provided an Unqualified opinion on the consolidated financial statements of

* Corresponding author, email address: nurenylolo@gmail.com 
PT Asuransi Jiwasyara (Persero) and its subsidiaries as of December 31, 2016. The audited Jiwasraya's net profit was IDR 1.7 trillion for 2016. Ironically, Jiwasraya announced that it could not pay the JS Saving Plan policy claim of IDR 802 billion due on October 10, 2018. A week later, the Ministry of StateOwned Enterprises (BUMN) suspected fraud in Jiwasraya's investment management (Hasiman, 2020). Another case occurred in Sunprima Nusantara Pembiayaan (SNP Finance). Deloitte, as the auditor, failed to detect a fraudulent scheme in SNP Finance's financial statements. SNP Finance had created fictitious receivables through fictitious sales. The receivables were pledged as collateral to the creditors. When the receivables were collected, the proceeds would be used to pay off the creditors' debt. To ensure the fictitious receivables, SNP Finance provided a fictitious document containing Columbia's customer data. Ironically, Deloitte's auditors, who were expected to detect this fraud, instead gave an Unqualified opinion on SNP Finance's financial statements (Handoko \& Soepriyanto, 2018).

On June 26, 2019, the Minister of Finance of the Republic of Indonesia gave sanctions to public accountants, such as Kasner Sirumapea and Tanubrata, Sutanto, Fahmi, and Bambang \& Rekan, as the auditors of the financial statements of PT. Garuda Indonesia for Fiscal Year 2018. Sanctions were given after the Ministry of Finance examined the public accountants regarding Garuda Indonesia's financial statements for the financial year 2018, particularly the revenue recognition from the co-operation agreement with PT Mahata Aero Teknologi. Related to this case, the Ministry of Finance revealed three Public Accountants' negligences in auditing the company's financial statements. Garuda Indonesia for the financial year 2018. First, the public accountants did not properly assess the transaction's substance for accounting treatment activities in recognition of receivables and other income. This was because the auditors recognized the receivable income even though the company had not had received it in nominal terms. Thus, the public accountant is proven to have violated the Audit Standard (SA) 315. Second, the public accountants had not fully obtained sufficient audit evidence to assess the accounting treatment in accordance with the substance of the transaction agreement. Third, the public accountants could not consider facts after the financial statements' date as the basis for accounting treatment that violated SA 560 (Hartomo, 2019).
Audit judgment is needed when dealing with uncertainty and limited information obtained, where auditors are required to make assumptions that can be used to make judgments, including evaluating judgments (Pawitra \& Suhartini, 2019). In making decisions, auditors are influenced by both internal and external factors. For auditors, these two factors have a very important role because they will consider many things other than the existing evidence when making judgments. One of the external factors is the complexity of the task. The auditors' attitude in dealing with their work can be influenced by the level of difficulty and complexity of the tasks at hand. It will affect the decisions to be taken by the auditors (Haid et al., 2017). The limited ability to integrate the problems faced makes auditors have to think about many things. As a result, it is not easy to provide quick and accurate judgment. Auditors can make mistakes when they face complex work and problems (Putri, 2017). The more complex the task faced by an auditor, the more he has to think and consider. Stuart \& Prawitt (2011) state that an auditor's complex tasks will make it difficult for him to provide a quick and accurate judgment so that the judgment becomes the solution faced.

Independence is one of the non-technical factors that can influence audit judgment. Auditors are required to be professional and independent in carrying out their duties. However, they sometimes face various threats to their independence, affecting their judgments (Johari et al., 2013; Setyaningrum \& Kuntadi, 2019). Threats to auditor's independence can come from the situation and work environment, actions, or relationships that are likely to affect auditors' ability to comply with basic ethical principles. Situation and environmental factors include non-audit services and the amount of audit fees (Skinner \& Vincent, 2001).

In carrying out their duties, the auditors will get a fee in accordance with the services provided. Previous researchers stated that the client's audit fees would affect the quality of the auditor's judgment. Task complexity is one indicator in measuring the amount of audit fees received by auditors. On the other hand, the size of the audit fee sometimes puts the auditor in a dilemma. It causes a decrease in auditor independence, which in turn affects the auditor in making a judgment (Farooq et al., 2018).

Some of the previous researchers who have tested the effect of task complexity and auditor independence on audit judgment are Sanusi et al. (2018), Putu et al. (2018), Muslim et al. (2018), 
Hamdani et al. (2014), and Pratama et al. 2018). This study only examines the effect of task complexity and auditor independence variables on audit judgment and whether audit fees moderate the effect of task complexity and auditor independence on audit judgment.

\section{THEORETICAL FRAMEWORK AND HYPOTHESES}

Information Processing Theory and Attribution Theory in the context of auditing

Human Information Processing (HIP) theory discusses the human way of thinking. Analyzing the human way of thinking is like a computer work process through a three-stage process. The first stage is inputting information. The second stage is processing information. Moreover, the third stage is releasing the processed information output in the form of ideas or behavior. The entry of information will stimulate the work of the brain. When the input contains good information, it will stimulate brain function optimally so that its work function is more optimal (Miller, 2016). According to Nguyen \& Kohda (2017), Human Information Processing (HIP) theory can be understood in making audit judgments. The judgment produced by an auditor is highly dependent on the information obtained by the auditor. When making the audit judgment, the auditor will process the information from the evidence obtained. The auditor must ensure the accuracy of the evidence and information obtained to produce an accurate audit judgment. The implementation of the HIP concept in making audit judgment is as follows: 1) the information obtained by the auditor from his client serves as input; 2 ) the auditor processes the information and considers the level of its accuracy, and 3) the auditor produces judgment on the audit results. When processing information, considering information, and producing judgment, the auditor is influenced by several factors, such as the complexity of the task and the threat to his independence.

One of the theories that underlie behavioral accounting is attribution theory. The concept of attribution theory is how a person explains the causes of behavior in others or oneself. A person's behavior can be caused by two factors, internal factors (dispositional attributions) and external factors (situational attributions). Internal factors come from within the individual himself, where everything is already in him, such as ability, knowledge, and effort. External factors refer to the environment that affects a person's behavior, which can result from pressure on certain situations or circumstances that force him to do certain actions, for example, difficulty in assignments and luck (Angkoso et al., 2014). Attribution theory is used to explain auditor judgment, performance appraisal, and auditor decision making. Attribution theory deals with judgment and explains how an auditor behaves. An auditor's capability to perform judgment when obtaining insufficient evidence is determined by internal attribution within the auditor. The capability can be formed through the auditor's efforts, for example, by maintaining independence, seeking knowledge, and increasing professional skepticism (Sonnier, 2015).

Task complexity, independence, and audit judgment

Task complexity is considered synonymous with difficult tasks and complex task structures that require attention capacity and good mental processes to determine the level of specification to be done in carrying out the task (Chung \& Monroe, 2019). The task of conducting audits tends to be one that faces many complex problems. Auditors are faced with complex tasks that are different and interrelated to one another. Audit complexity is based on the individual's perception of the difficulty of the audit task. Some auditors consider the audit task as a task with high and difficult task complexity. In contrast, other auditors consider it an easy task.

To carry out their complex tasks, auditors, as members of the audit team, require a high level of expertise, ability, and patience. There are two aspects to the task's complexity: 1) the difficulty level of the task, which is always associated with the amount of information; and 2) task structure, which is always associated with clarity of information (Hærem el al., 2015). Furthermore, according to Hærem et al. (2015), task complexity is thought to affect auditor performance, so it is necessary to test the task's complexity for an audit situation.

High task complexity can affect the judgments made by auditors (Sanusi et al., 2018). When an auditor feels that the audit task he is facing is complicated and has difficulties carrying it out, he cannot make a professional judgment (Chung \& Monroe, 2019). The results of research conducted by Sanusi et al. (2007) show that task complexity has a dominant effect on audit judgment. As a result, the judgment taken by the auditor is not based on the evidence obtained.

$\mathbf{H}_{1}$ : Task complexity affects audit judgment 
Independence means that an auditor must be free from any influence, not under control and dependent on other parties, or not influenced by various activities, both from outside and from within the auditor, in considering in the field. Independence is evidence of impartiality or conformity with the rules in carrying out tasks procedurally to produce audit opinions (Arens, Elder, \& Beasley, 2016: 55). Auditor independence serves to reduce bias in work. Auditors often face a higher level of competition between public accounting firms, which in turn leads to violations of auditor independence.

An independent auditor will have the ability to be assertive in making impartial and consistent decisions according to the information obtained to produce the right judgment. Several previous studies have found that auditor independence affects auditor judgment. The research results conducted by Julia \& Sudana (2015) show that auditors who have high independence tend to produce more accurate audit judgments. A more precise and accurate judgment can be made because the auditors have a high level of independence.

\section{$\mathbf{H}_{2}$ : Independence affects audit judgment}

Audit fees are fees received by an auditor after performing audit services. Audit fees are determined based on the auditor's duties. The amount of fees given to the auditor depends on the complexity of the services or tasks provided, the level of risk of the assignment received, the level of expertise required to perform these services, the cost structure of the Public Accounting Firm concerned, and other professional considerations (Safi'i \& Jayanto, 2015).

Members of the Public Accounting Firm are not allowed to get clients by offering fees that can damage their professional image (Sulfati, 2016). The complexity of the auditor's tasks will affect judgment (Fitriani \& Daljono, 2012). The complexity of the task performed varies from one auditor to another. On the other hand, the complexity of the tasks received by the auditor determines the audit fees. Therefore, the size of audit fees can strengthen the effect of task complexity on audit judgment.

\section{$\mathbf{H}_{3}$ : Audit fees moderate the effect of task complexity} on audit judgment.

Auditors must maintain their independence, intellectual honesty, and freedom from conflicts of interest, so that independence is an essential characteristic of auditors (Skinner \& Vincent, 2001). All interested parties depend on the fairness of the auditor's report's financial statements because they expect to obtain an impartial opinion from the auditor's judgment. For the services provided, the auditor is rewarded with an audit fee. The size of audit fees can affect the independence of auditors. Auditors who receive large audit fees can feel dependent on clients and are afraid of losing clients to interfere with the independence of the auditors (Sari \& Widanaputra, 2016). On the other hand, a small audit fee may result in limited time and cost to perform audit procedures and cause the auditor's information to be limited, thus affecting the auditor's judgment.

$\mathbf{H}_{4}$ : Audit fees moderate the effect of independence on audit judgment.

\section{RESEARCH METHOD}

This research population is all auditors who work in Public Accounting Firms in West Jakarta and South Jakarta that are registered with the Indonesian Public Accountants Association (IAPI). Sampling was conducted using a convenience sampling technique. Respondents were not limited by auditors' position in Public Accounting Firms (partners, managers, senior auditors, and junior auditors) so that all auditors who worked in Public Accounting Firms could be included as respondents.

Data collection was carried out using the field research method by distributing questionnaires directly to respondents who work at the Public Accounting Firms and through several intermediaries or contact persons, accompanied by a letter of request addressed to the Public Accounting Firms' heads. The Public Accounting Firms then referred staff according to the required criteria. Furthermore, respondents were asked to fill out a list of questions contained in the questionnaire. The questionnaire consisted of two parts. The first part contained some frequently asked questions about the demographics of the respondents. The second part contained several questions related to the complexity of the task and the audit judgment's independence with audit fees as the modifying variable.

Both the independent and dependent variables were measured using a Likert scale. The variables to be measured were translated into variable indicators. These indicators were used as a starting point for the preparation of instrument items in questions or statements. The answer for each instrument item used a Likert scale ranging from 
very positive to very negative. Research variables, dimensions, and variable indicators are presented in Table 1.

The data quality test was done through validity and reliability tests. Data analysis was performed using Moderated Regression Analysis. The analysis included descriptive statistical analysis, regression analysis, classical assumption test, and hypothesis testing. The classical assumption test included normality, multicollinearity, heteroscedasticity, and autocorrelation tests. Hypothesis testing was done using the t-test.

Table 1. Variable, Dimension, and Variable Indicator

\begin{tabular}{|c|c|c|}
\hline Variable & Dimension & Indicator \\
\hline $\begin{array}{l}\text { X1: Task } \\
\text { Complexity }\end{array}$ & $\begin{array}{l}\text { 1. Task } \\
\text { difficulty levels }\end{array}$ & $\begin{array}{l}\text { a. The auditing task is a task with a high task } \\
\text { complexity } \\
\text { b. How to do the types of tasks that must be } \\
\text { done } \\
\text { c. Duties relating to all business functions } \\
\text { a. The position shows what must be done } \\
\text { b. To know clearly what the company } \\
\text { expects } \\
\text { c. Supervision and review (in the form of } \\
\text { corrections) from superiors really help to } \\
\text { understand tasks clearly. }\end{array}$ \\
\hline $\begin{array}{l}\text { X2: Auditor } \\
\text { Independence }\end{array}$ & $\begin{array}{l}\text { 1. Independence } \\
\text { in act } \\
\text { 2. Independence } \\
\text { In relationship }\end{array}$ & $\begin{array}{l}\text { a. Honesty when doing the examination. } \\
\text { b. Honesty when gathering evidence } \\
\text { a. Honesty that there is no co-operation } \\
\text { bith clients } \\
\text { b. Honesty that there is no family ties }\end{array}$ \\
\hline \multirow[t]{3}{*}{ X3: Audit Fee } & $\begin{array}{l}\text { 1. The complexity of } \\
\text { the services } \\
\text { provided. }\end{array}$ & $\begin{array}{l}\text { a. The amount of the audit fee is based on } \\
\text { the complexity of the audit. } \\
\text { b. The amount of the audit fee is determined } \\
\text { by the level of expertise. } \\
\text { c. The amount of the audit fee is determined } \\
\text { by the effort to get clients. }\end{array}$ \\
\hline & $\begin{array}{l}\text { 2. Fee structure and } \\
\text { other professional } \\
\text { considerations }\end{array}$ & $\begin{array}{l}\text { a. To audit high-risk business entities with } \\
\text { large fees. } \\
\text { b. The fee structure of the Public Accounting } \\
\text { Firm does not influence the amount of the } \\
\text { audit fee. }\end{array}$ \\
\hline & 3. Firm size & $\begin{array}{l}\text { a. The size of the Public Accounting Firm } \\
\text { determines the amount of the audit fee. } \\
\text { b. To accept clients who pay large fees. }\end{array}$ \\
\hline \multirow[t]{2}{*}{$\begin{array}{l}\text { Y: Audit } \\
\text { Judgment }\end{array}$} & $\begin{array}{l}\text { 1. Determination of } \\
\text { the material level }\end{array}$ & $\begin{array}{l}\text { a. To consider the level of the materiality of } \\
\text { the financial statements. } \\
\text { b. To consider the level of the materiality of } \\
\text { the account balance. } \\
\text { c. Consideration of the materiality requires } \\
\text { expertise and experience. }\end{array}$ \\
\hline & 2. Audit risk level & $\begin{array}{l}\text { a. To consider the inherent risk. } \\
\text { b. To determine the risk of controlling } \\
\text { individual account balances. } \\
\text { c. To follow supervisor's instructions and } \\
\text { exclude violations from the confirmation } \\
\text { process. }\end{array}$ \\
\hline
\end{tabular}

Source: Author's data analysis 


\section{DATA ANALYSIS AND DISCUSSION}

Based on the Directory of Public Accountants, there are 240 Public Accounting Firms throughout Jakarta, consisting of 27 Public Accounting Firms in West Jakarta and 87 Public Accounting Firms in South Jakarta. Based on the specified sample selection criteria, 12 Public Accounting Firms in West Jakarta and South Jakarta were selected to be examined. Respondents in this study were auditors who worked in Public Accounting Firms in West Jakarta and South Jakarta and were used as samples of this study. The number of questionnaires distributed was 120 for 12 Public Accounting Firms in West
Jakarta and South Jakarta. The number of questionnaires returned was $100(83.33 \%)$, and the number of questionnaires not returned was 20 $(16.67 \%)$. This is because the questionnaires were distributed while the participants were busy auditing outside the office.

The results of the data validity test indicate that the data meets the validity value. The Cronbach Alpha value is $>0.7$, which means that the data is reliable. Table 2 shows respondents' demographic data based on age, gender, position, latest education, and years of service. Descriptive statistics are shown in table 3:

Table 2. Respondent Demographics Data

\begin{tabular}{|c|c|c|c|}
\hline Characteristics & & Total Respondents & $(\%)$ \\
\hline \multirow{4}{*}{ Age } & $<30$ years & 55 & $55 \%$ \\
\hline & $30-40$ years & 25 & $25 \%$ \\
\hline & $>40$ years & 20 & $20 \%$ \\
\hline & Total & 100 & $100 \%$ \\
\hline \multirow{3}{*}{ Gender } & Man & 54 & $54 \%$ \\
\hline & Woman & 46 & $46 \%$ \\
\hline & Total & 100 & $100 \%$ \\
\hline \multirow{5}{*}{ Position } & Junior Auditor & 50 & $50 \%$ \\
\hline & Senior Auditor & 46 & $46 \%$ \\
\hline & Manager & 2 & $2 \%$ \\
\hline & Partner & 2 & $2 \%$ \\
\hline & Total & 100 & $100 \%$ \\
\hline \multirow{5}{*}{ Latest Education } & Bachelor & 65 & $65 \%$ \\
\hline & Master & 20 & $20 \%$ \\
\hline & Doctorate & 6 & $6 \%$ \\
\hline & Other & 9 & $9 \%$ \\
\hline & Total & 100 & $100 \%$ \\
\hline \multirow{4}{*}{ Years of service } & $<1$ year & 15 & $15 \%$ \\
\hline & $1-3$ years & 58 & $58 \%$ \\
\hline & $>3$ years & 27 & $27 \%$ \\
\hline & Total & 100 & $100 \%$ \\
\hline
\end{tabular}

Source: Author's data analysis

Table 2 shows the demographic data of respondents. Most respondents are at an age less than $(<) 30$ years $(55 \%)$ and male $(54 \%)$. There are $50 \%$ junior auditors and $46 \%$ senior auditors. Based on the latest education, $65 \%$ are bachelors, $20 \%$ are masters, and $6 \%$ are doctorates. Most respondents have service years of one to three years $(58 \%)$. 
Table 3. Descriptive statistics

\begin{tabular}{|c|c|c|c|}
\hline Variable & Dimensions & Indicators/Question Items & Mean \\
\hline \multirow{6}{*}{$\begin{array}{l}\text { Task Complexity } \\
\text { (TAKSCMPLEX) }\end{array}$} & \multirow[t]{3}{*}{ 1. The task difficulty levels } & TC1 & 3,53 \\
\hline & & TC2 & 3,23 \\
\hline & & TC3 & 3,41 \\
\hline & \multirow[t]{3}{*}{ 2. Task Structure } & TC4 & 3,09 \\
\hline & & TC5 & 3.22 \\
\hline & & TC6 & 3.20 \\
\hline \multirow{6}{*}{$\begin{array}{l}\text { Independence } \\
\text { (INDP) }\end{array}$} & \multirow[t]{3}{*}{ 1. Independence in act } & INDP1 & 3,88 \\
\hline & & INDP2 & 3,87 \\
\hline & & INDP3 & 3,90 \\
\hline & \multirow{3}{*}{$\begin{array}{l}\text { 2. Independence } \\
\text { in relationship }\end{array}$} & INDP4 & 3,84 \\
\hline & & INDP5 & 3,88 \\
\hline & & INDP6 & 3,82 \\
\hline \multirow[t]{7}{*}{ Audit Fee (AF) } & \multirow{3}{*}{$\begin{array}{l}\text { 1. The complexity of the } \\
\text { services provided }\end{array}$} & AF2 & 4,09 \\
\hline & & AF3 & 4,48 \\
\hline & & AF4 & 4,06 \\
\hline & \multirow{2}{*}{$\begin{array}{l}\text { 2. Fee structure and other } \\
\text { professional considerations }\end{array}$} & AF5 & 3,98 \\
\hline & & AF6 & 3,90 \\
\hline & \multirow[t]{2}{*}{ 3. Firm Size } & AF7 & 3,76 \\
\hline & & AF8 & 3,99 \\
\hline \multirow{6}{*}{$\begin{array}{l}\text { Audit Judgment } \\
\text { (AUDJUDG) }\end{array}$} & \multirow{3}{*}{$\begin{array}{l}\text { 1. Determination of the } \\
\text { material level }\end{array}$} & AJ1 & 3,13 \\
\hline & & AJ2 & 3,44 \\
\hline & & $\mathrm{AJ} 3$ & 3,45 \\
\hline & \multirow[t]{3}{*}{ 2. Audit risk level } & AJ4 & 3,48 \\
\hline & & AJ5 & 2,95 \\
\hline & & AJ6 & 3,69 \\
\hline
\end{tabular}

Source: Author's data analysis

The classical assumption test and Kolmogorov Smirnov Test results show that the data are normally distributed with a probability value of $0.200(0.200>$ $0.05)$. There is no autocorrelation, as shown by the value of $\mathrm{du}<\mathrm{dw}<4-\mathrm{du}(1.67<1.785<210)$. The results of the heteroscedasticity test show that there is no heteroscedasticity. The Variance Inflation Factor (VIF) test results show that the value is smaller than 10 , meaning that there is no multicollinearity.

Data analysis was performed using Moderated Regression Analysis (MRA) to test the effect of task complexity and independence on audit judgment and test the variable of audit fee as a moderating variable for task complexity and independence on audit judgment. The MRA or interaction test is a multiple linear regression analysis where the regression equation contains interaction elements (Lie, 2009). First, testing was done partially to determine the effect of task complexity on audit judgment and the effect of the variable of independence on audit judgment to answer hypothesis 1 and hypothesis 2 . Second, testing was done to determine audit fees' interaction on the effect of task complexity and independence on audit judgment to answer hypotheses 3 and hypothesis 4 . The results of the Moderated Regression Analysis test are shown in Table 4. 
Nur Eny, Moderating Role of Audit ees on the Effect of Task Complexity and Independence towards...

Table 4. Moderated Regression Analysis Test Results

\begin{tabular}{|c|c|c|c|c|c|}
\hline \multirow{2}{*}{ Variable } & \multicolumn{2}{|c|}{$\begin{array}{l}\text { Unstandardized } \\
\text { Coefficients }\end{array}$} & \multirow{2}{*}{$\begin{array}{l}\text { Standardized } \\
\text { Coefficients } \\
\text { Beta }\end{array}$} & \multirow[t]{2}{*}{$\mathbf{t}$} & \multirow[t]{2}{*}{ Sig } \\
\hline & B & Std. Error & & & \\
\hline (Constant) & 19.050 & 30.869 & & 3.533 & 0.001 \\
\hline TAKSCPLEX & -0.606 & 1.076 & -3.147 & 2.421 & 0.017 \\
\hline INDP & 0.343 & 0.680 & 1.242 & 1.976 & 0.048 \\
\hline $\mathrm{AF}$ & 0.917 & 0.914 & 3.347 & 3.191 & 0.002 \\
\hline TAKSCPLEX *FA & 0.091 & 0.032 & 4.154 & 2.790 & 0.006 \\
\hline \multirow[t]{6}{*}{$\mathrm{INDP} * \mathrm{AF}$} & 0.041 & 0.020 & 1.750 & 2.060 & 0.042 \\
\hline & \multicolumn{2}{|l|}{$\mathrm{R}$} & & \multicolumn{2}{|l|}{$0.563^{\mathrm{a}}$} \\
\hline & \multicolumn{2}{|l|}{$\mathrm{R}^{2}$} & & \multicolumn{2}{|l|}{0.316} \\
\hline & \multicolumn{2}{|c|}{ Adjusted R Square } & & \multicolumn{2}{|l|}{0.280} \\
\hline & \multicolumn{2}{|l|}{$\mathrm{F}$} & & \multicolumn{2}{|l|}{8.704} \\
\hline & \multicolumn{2}{|c|}{ Significance F } & & \multicolumn{2}{|l|}{$0.000^{\mathrm{b}}$} \\
\hline
\end{tabular}

Dependent Variable: Audit Judgment

Source: Author's data analysis

The test results in Table 4 show that task complexity has a negative and significant effect on audit judgment. So, the first hypothesis (H1) is accepted. This means that complex task condition affects the auditor's judgment in determining his opinion. The negative direction of the relationship indicates that the higher the complexity of the auditor's tasks, the lower the quality of the audit judgment will be. When faced with high task complexity, the auditor will experience difficulties in completing his duties (Yustrianthe, 2012).

Difficult tasks require more individual abilities to complete. If the task's complexity is greater than the auditor's ability, it will raise concerns about whether he can complete the task properly. Such conditions will result in a decrease in auditor performance. In the end, the auditor is unable to integrate information into a sound judgment, thus affecting the auditor's opinion. The results of this study support the results of research conducted by Sanusi et al. (2018), Putu et al. (2018), Muslim et al. (2018), which state that task complexity hurts audit judgment.

Table 4 shows that independence affects audit judgment. So, the second hypothesis (H2) is accepted. Auditors who have high independence will have a better judgment on the audit results and will produce a more precise and accurate opinion. Conversely, auditors who are unable to maintain their independence tend to produce inaccurate audit judgments. The results of this study support the results of previous studies conducted by Hamdani et al. (2014), Shintya et al. (2016), and Pratama et al. (2018). The results of this study indicate that independence has a positive influence on audit judgment. This study's findings provide an understanding that one of the attributes that determine auditor judgment based on morals and ethics is auditor independence (Budisusetyo, 2018). Therefore, to maintain financial statements' integrity, auditors are required to maintain their independence as one of the essential auditor characteristics (Johari et al., 2013).

\section{Audit Fee Moderates the Effect of Task Complexity on the Audit Judgment}

This study shows that the variable of audit fees moderates the effect of task complexity on audit judgment. So, the third hypothesis (H3) is accepted. The size of audit fee is determined based on the risk of the assignment, the complexity of the services provided, the cost structure of Public Accounting Firms, professional considerations, and the size of the Public Accounting Firms, thus strengthening the task's effect complexity on the auditor's judgment.

To perform difficult and complex tasks requires a high level of expertise. A large and reputable Public Accounting Firm is usually better able to provide competent and skilled personnel because it can pay high fees for its auditors and afford the required audit technology and training. On the other hand, this 
reputable Public Accounting Firm usually has a high fee structure. It will have an impact on the size of the fee that clients must pay.

Public Accounting Firms that receive high fees will pay their auditors a high fee as well. This allows the auditors to have a long time to gather additional evidence and information to produce an appropriate assessment of the financial statements being audited (Irawati \& Badingatus, 2018). This study also reinforces the understanding that competent auditors can produce better and more accurate judgment. This is because they work in a reputable public accounting firm that can pay them high fees to accept complex and high-risk assignments.

\section{Audit Fee Moderates the effect of Independence on Audit Judgment}

This study also shows that the variable of audit fees moderates the effect of independence on audit judgment. So, the fourth hypothesis (H4) is accepted, which means that the audit fee amount can strengthen the influence of independence on the judgment audit. High independence will result in accurate judgment. With the audit fee, auditors will be more able to maintain their independence, resulting in more accurate judgments.

An auditor does not easily maintain his independence when he is faced with difficult decisions. Auditors usually face pressure from clients in various decisions. If the auditor cannot cope with pressures, such as personal, emotional, or financial pressures, the auditor's independence will decrease, which will affect his judgment. Besides, fees paid to auditors can interfere with auditors' independence, which in turn can have an impact on decision making. Thus, this study's findings provide an understanding that audit fees can strengthen the effect of auditor independence on audit judgment.

\section{CONCLUSION, IMPLICATION, SUGGESTION, AND LIMITATIONS}

Based on the analysis results, it can be concluded that task complexity hurts audit judgment. This means that the complexity of the tasks faced by auditors will result in decreased audit judgment quality. This decline in auditor performance is caused by the complexity of the auditor's tasks so that he cannot integrate information into good judgment in determining an opinion. Independence affects audit judgment. This means that the higher the auditor's independence, the better the auditor's judgment will be, resulting in a more precise and accurate opinion in presenting the audit results.
Conversely, auditors who are unable to maintain their independence are likely to produce inaccurate audit judgments. Audit fees moderate the effect of task complexity on audit judgment. Therefore, the audit fees can strengthen the effect of task complexity on the auditor's judgment. In other words, complex and complicated tasks will affect the auditor's judgment, which can be moderated by the amount of audit fees received by the auditor. Audit fees can strengthen the influence of independence on audit judgment. In other words, an auditor's independence will result in the right judgment with the presence of audit fees. The auditor will further strengthen his independence to produce an increasingly accurate judgment.

This study has implications for providing empirical evidence that auditors are required to make the right decisions, which are used in determining judgments. Analysis of external and internal factors can help explain how auditors interact when making decisions. The audit process that considers the interaction of variables that affect audit judgment, such as task complexity, independence, and audit fees, is expected to help practitioners resolve and reduce unhealthy practices.

This study has a limited number of samples in Jakarta, and most respondents are junior auditors. This study only examines two variables related to audit costs as a moderating variable affecting audit judgment. Further research can be carried out in a broader scope by involving more senior auditors as respondents. Research on the factors that influence audit judgment has been conducted with various findings, both consistent and inconsistent, so it can be said to be saturated. In addition to adding variables, it is suggested that the next researchers conduct mapping and meta-analysis to determine the variables that have the most influence on auditor's judgment.

\section{REFERENCES}

Angkoso, C. D., Subroto, B., \& Sutrisno, S. (2014). The role of situational and individual factors on the premature sign-offs of audit procedures. IOSR Journal of Economics and Finance, 5(6), 5768.

Arens, A. A., Elder, R. J., \& Beasley, M. S. (2016). Auditing and assurance services, Global Edition. Pearson Education UK

Budisusetyo, S. (2018). Moral character: challenges for auditors in serving public interest. Journal of Economics, Business, \& Accountancy Ventura, 21(1), 61-77. 
Chung, J. \& Monroe, G. S. (2019). The effects of gender and task complexity on audit judgment. In The Grants Register 2020 (Issue 1998). Palgrave Macmillan UK.

Farooq, M. U., Irfan, K., Usman, M., \& Latif, I. (2018). Corporate governance and audit fees: evidence from a developing country. Pakistan Journal of Commerce and Social Sciences, 12((1) May), 94110.

Fitriani \& Daljono. (2012). Pengaruh tekanan ketaatan, kompleksitas tugas, pengetahuan dan persepsi etis terhadap audit judgement. Diponegoro Journal of Accounting, 1(1), 1-12.

Hærem, T., Pentland, B. T., \& Miller, K. D. (2015). Task complexity: Extending a core concept. Academy of Management Review, 40(3), 446-460.

Haid, Marco., Graschitz, S., and Mueller, C. (2017). Auditor's characteristics, liability regime and task complexity assessment. Proceeding: 13th European Conference on Management, Leadership and Governance, 37-46.

Hamdani, R, Zirman, \& Anisma, Y. (2014). Pengaruh tekanan ketaatan, independensi, kompleksitas tugas dan etika terhadap audit judgment. JOM Fekom, 1(2), 1-15.

Handoko, B. L. \& Soepriyanto, G. (2018). Merunut kasus SNP Finance \& Auditor Deloitte Indonesia. Binus University. https:/ /accounting.binus.ac.id/2018/12/03/m erunut-kasus-snp-finance-auditor-deloitteindonesia-2/

Hartomo, G. (2019). Kronologi kasus laporan keuangan Garuda Indonesia hingga kena sanksi.

https:/ / economy.okezone.com/read/2019/06 /28/320/2072245/kronologi-kasus-laporankeuangan-garuda-indonesia-hingga-kenasanksi

Hasiman, F (2020). Megaskandal Jiwasraya. Bisnis.Com.

https:/ / finansial.bisnis.com/read/20200131/2 15/1196058/megaskandal-jiwasraya

Irawati, A, S. \& Badingatus, S. (2018). Factors affecting audit judgment. Accounting Analysis Journal, 7(1), 34-42.

Johari, R., Sanusi, Z., Rahman, R., \& Omar, N. (2013). Auditors' independence, experience, and ethical judgments: The case of Malaysia. Journal of Business and Policy Research, 8(1), 100-119.

Julia, M. D. \& Sudana, I. P. (2015). Pengaruh keahlian auditor, tekanan ketaatan dan independensi pada audit judgmenet. E-Jurnal Akuntansi Universitas Udayana., 12(3), 623-655.

Lie, L. (2009). Penggunaan mra dengan spss untuk menguji pengaruh variabel moderating terhadap hubungan antara variabel independen dan variabel dependen. Jurnal Teknologi Informasi DINAMIK, XIV(2), 90-97.

Miller, H. L. (2016). Human Information Processing. In The SAGE Encyclopedia of Theory in Psychology. SAGE Publications, Inc.

Muslim, Faisal, A. Pelu. M., \& Mentari. (2018). Pengaruh kompetensi auditor, tekanan ketaatan, dan kompleksitas tugas terhadap audit judgment. Bongaya Journal for Research in Accounting (BJRA), 1(2), 08-17.

Nguyen, L. \& Kohda, Y. (2017). Toward a knowledge management framework for auditing processes. International Journal of Knowledge and Systems Science, 8(3), 45-67.

Pasanda, E., \& Paranoan, N. (2013). Pengaruh gender dan pengalaman audit terhadap audit judgment. Jurnal Akuntansi Multiparadigma, 4(3), 417-429.

Pratama, B. C., Ahmad, Z. A., \& Innayah, M. N. (2018). Obedience pressure, professional ethics, attitude of skepticism and independency towards audit judgment. Journal of Accounting Science, 2(2), 141-149.

Pawitra, D. A. K. \& Suhartini, D. (2019). The influence of individual behavioral aspects toward audit judgment: the mediating role of self-efficacy. Journal of Economics, Business, $\mathcal{E}$ Accountancy Ventura, 22(2), 264-273.

Putri, A. R. (2017). Pengaruh tekanan anggaran waktu, kompleksitas tugas, pengetahuan auditor, dan pengalaman auditor terhadap audit justment (Studi kasus pada KAP di Pekanbaru, Batam, dan Padang). JOM Fekon, 4(1), 1282-1294.

Putu, L. S. S. ., Dewi, C. I. R. S., \& C. Krisna Yudha. (2018). Pengaruh kompleksitas tugas pada audit judgment dengan variabel religiusitas sebagai pemoderasi. Aksioma Jurnal Riset Akuntansi, 17(2), 225-258.

Safi'i, T. A. \& Jayanto. P. Y. (2015). Analisis faktorfaktor yang berpengaruh terhadap audit judgement. Accounting Analysis Journal, 4(4), 119.

Sanusi, Z. M., Iskandar, T.M., Monroe, G.S., \& Saleh, N. (2018). Effects of goal orientation, selfefficacy and task complexity on the audit judgment performance of Malaysian auditors. Accounting, Auditing \& Accountability Journal, Volume 31(1), 75-95.

Sanusi Z. M., Iskandar. T. M., \& Poon, J. (2007). Effects of goal orientation and task complexity on audit judgment performance. Malaysian 
Accounting Review, 6(January), 123-139.

Sari. I W. I. \& Widanaputra, A. A. G. (2016). Reputasi auditor sebagai pemoderasi pengaruh audit fee pada auditor switching. E.Jurnal Akuntansi Universitas Udayana, 16(1), 527-556.

Setyaningrum, D. \& Kuntadi, C. (2019). The effects of competence, independence, audit work, and communication on the effectiveness of internal audit. Journal of Economics, Business, $\mathcal{E}$ Accountancy Ventura, 22(1), 39-47

Shintya, A., Nuryatno, M., \& Oktaviani, A. A. (2016). Pengaruh kompetensi, independensi dan tekanan anggaran waktu terhadap kualitas audit. Proceeding Seminar Cendekiawan 2016, 119.

Skinner, D. J. \& Vincent, L. (2001). SEC auditor independence requirements. Accounting Horizons, 15(4), 373-386.
Sonnier, B. M. (2015). The influence of source credibility and attribution of blame on juror evaluation of liability of industry specialist auditors. Journal of Forensic $\mathcal{E}$ Investigative Accountant, 7(1), 1-37.

Stuart, I. \& Prawitt, D. F. (2011). The influence of audit structure on auditors' performance in high and low complexity task settings. SSRN Electronic Journal, September 2016.

Sulfati, A. (2016). Pengaruh fee dan tenure audit terhadap kualitas audit pada kantor akuntan publik. Seminar Nasional and The 3rd Call for Syariah Paper, 602-610.

Yustrianthe, R. H. (2012). Beberapa faktor yang mempengaruhi audit judgment auditor pemerintah. Jurnal Dinamika Akuntansi, 4(2), 7282. 